Egyptian Journal of Aquatic Biology \& Fisheries

Zoology Department, Faculty of Science,

Ain Shams University, Cairo, Egypt.

ISSN $1110-6131$

Vol. 25(2): 1081 - 1091 (2021)

www.ejabf.journals.ekb.eg

\title{
Indigenous Microorganisms in Agriculture Drains
}

\author{
Mohamed Saber ${ }^{1}$, Hoda Kabary ${ }^{1}{ }^{*}$, Fatma Helmi ${ }^{1}$, Dalia Abd-El-Mowla ${ }^{1}$, \\ Alaa Zaghloul ${ }^{2}$
}

1. Agricultural Microbiology Department, Agricultural and Biological Research Division, National Research Centre

2. Soils and Water Use Department, National Research Centre

"Corresponding Author: hoda_kabary@yahoo.com

\section{ARTICLE INFO}

Article History:

Received: April 19, 2021

Accepted: April 27, 2021

Online: May 10, 2021

Keywords:

Indigenous microorganisms,

Agriculture drain,

total bacteria,

total fungi,

phosphate dissolving

bacteria,

cellulose decomposers

\section{ABSTRACT}

From two sites at each of El-Rahawi and Belbeis agriculture drains located at Nile Delta as well as from river Nile, one surface water sample from each was collected, and their indigenous microbial intensities were estimated. The studied indigenous microorganisms included total bacteria, total fungi, Azotobacter sp., Clostridium sp., Pseudomonas sp., phosphate dissolving bacteria and cellulose decomposers. Results revealed that the counts of bacteria, fungi, Azotobacter sp., Clostridium sp., Pseudomonas sp., phosphate dissolving bacteria and cellulose decomposers were $93 \times 10^{6}, 1 \times 10^{6}, 1 \times 10^{3}$, $6 \times 10^{6}, 27 \times 10^{6}, 1 \times 10^{6}, 2 \times 10^{6}$ and $18 \times 10^{6}, 2 \times 10^{6}, 1 \times 10^{4}, 7 \times 10^{6}, 25 \times 10^{6}, 25 \times 10^{6}$, $2 \times 10^{6}$ respectively at El-hod and El-hadar sites at El-Rahawi agriculture drain. Whereas, the counts of bacteria, fungi, Azotobacter sp., Clostridium sp., Pseudomonas sp., phosphate dissolving bacteria and cellulose decomposers were within the range of $62 \times 10^{6}, 1 \times 10^{6}, 1 \times 10^{2}, 30 \times 10^{6}, 20 \times 10^{6}, 1 \times 10^{6}$ and $7 \times 10^{6}$ and of $50 \times 10^{6}, 2 \times 10^{6}, 1 \times 10^{4}, 79 \times 10^{7}, 6 \times 10^{6}, 88 \times 10^{6}$ and $75 \times 10^{6}$ respectively at the Bridge and Mosque sites at Belbeis agriculture drain. However, the counts of bacteria, fungi, Azotobacter sp., Clostridium sp., Pseudomonas sp., phosphate dissolving bacteria and cellulose decomposers were within the range of $57 \times 10^{6}, 2 \times 10^{4}, 1 \times 10^{2}, 45 \times 10^{6}, 7 \times 10^{6}, 1 \times 10^{6}$ and $2 \times 10^{6}$ respectively in River Nile water. The functions of the studied indigenous biotas existing in drainage water and soil ecosystem and crops are discussed.

\section{INTRODUCTION}

The use of drainage water in irrigation not only alleviate pressure on fresh water resources significantly, but also lessen the discharge of effluents into water ecosystem hence avoiding the deterioration of fresh water ecosystems associated with eutrophication and algal bloom (Toze, 2006). The use of drainage water in irrigation had also been found to have additional agronomic benefits associated with soil and plant health. Diverse studies had shown that irrigation with drainage water irrigation fortified soil biotas (Mañas et al., 2009). However, irrigation with drainage water is also associated with several biological risks such as the dissemination of pathogenic viruses, helminthes and 
protozoa in the soil ecosystem (Samie et al., 2009) that had opened a new controversial front in the public debate (Phung and Rodgers, 2011).

Indigenous microorganisms are a group of innate microbial consortium that inhabits terrestrial and aquatic ecosystems and have potent impacts on soil health (Umi Kalsom, 2006) and are considered as the most important component of world biodiversity (Sadi et al., 2006). Indigenous microorganisms increase the availability of nutrients in soil ecosystems to host plants (Vessey, 2003) and improve soil aeration in rhizoshere due to gases exchange. No doubt, indigenous biotas existing in drainage water have major functions on soil and crop health, yet up to now to the best of our knowledge, only few studies cared about these functions especially on the soil the bacterial community composition due to the long-term use of drainage water irrigation. However, the use of indigenous microorganisms to get economic, social and environmental benefits is inherently attractive (Cai et $\mathbf{a l . ,}$ 2013).

The aim of the current work is to estimate the intensities of indigenous microorganisms existing in drainage water and their effect on soil health and grown crops.

\section{MATERIALS AND METHODS}

\section{WATER SAMPLING}

Drainage water samples were collected from two sites at each of two agricultural drains located in Nile delta, i.e., Belbeis and 1-Rahawi as well as one sample from river Nile at Tanash village, Warak for comparison during October 2020 to explore their indigenous microorganisms. The first site at El-Rahawi drain is at the entrance pan of the drain after El-Rahawi barrage and second one was after the fall close to the ending point of the drain.

\section{METHODS}

The intensities of indigenous microorganisms in the water samples collected from two sites at two agriculture drains in Nile delta, Belbeis and El-Rahawy, were measured and compared with those in the river Nile water. The counted indigenous microorganisms in the current study included total bacteria, total fungi, Azotobacter sp., Clostridium sp., Pseudomonas sp., phosphate dissolving bacteria and cellulose decomposers.

Ten $\mathrm{ml}$ portions of the drain water sample were diluted in $90 \mathrm{ml}$ sterilized water to form the first dilution factor $\left(10^{1}\right)$. Thereafter serial of dilutions were done on the $10^{1}$ factor until reaching the dilution of factor $10^{6}$.

Bacteria, fungi, Azotobacter sp., Clostridium sp., Pseudomonas sp. were counted on nutrient agar, rose Bengal, Ashby, Tryptic soy Cycloserine amended with 0.4\% keramycin and Kings B media respectively (APHA 2005 and Merck Microbiological Manual 2010). tryptic soy Cycloserine agar plates were incubated in anaerobic jars at 37 
${ }^{\circ} \mathrm{C}$, while the other plates and tubes were incubated at $30{ }^{\circ} \mathrm{C}, 24-48$ hours for bacteria and 72- 96 hours for fungi under aerobic condition.

\section{RESULTS}

The intensities of studied indigenous microbial groups in both selected sites at each of ElRahawi and Belbeis agriculture drains as well as in river Nile waters are given in Table (1). Results revealed that the counts of bacteria, fungi, Azotobacter sp., Clostridium sp., Pseudomonas sp., phosphate dissolving bacteria and cellulose decomposers were $93 \times 10^{6}$, $1 \times 10^{6}, 1 \times 10^{3}, 6 \times 10^{6}, 27 \times 10^{6}, 1 \times 10^{6}, 2 \times 10^{6}$ and $18 \times 10^{6}, 2 \times 10^{6}, 1 \times 10^{4}, 7 \times 10^{6}, 25 \times 10^{6}$, $25 \times 10^{6}, 2 \times 10^{6}$ respectively at El-hod and El-hadar sites at El-Rahawi agriculture drain. Whereas, the counts of bacteria, fungi, Azotobacter sp., Clostridium sp., Pseudomonas sp., phosphate dissolving bacteria and cellulose decomposers were within the range of $62 \times 10^{6}, 1 \times 10^{6}, 1 \times 10^{2}, 30 \times 10^{6}, 20 \times 10^{6}, 1 \times 10^{6}$ and $7 \times 10^{6}$ and of $50 \times 10^{6}, 2 \times 10^{6}, 1 \times 10^{4}$, $79 \times 10^{7}, 6 \times 10^{6}, 88 \times 10^{6}$ and $75 \times 10^{6}$ respectively at the Bridge and Mosque sites at Belbeis agriculture drain. However, the counts of bacteria, fungi, Azotobacter sp., Clostridium sp., Pseudomonas sp., phosphate dissolving bacteria and cellulose decomposers were within the range of $57 \times 10^{6}, 2 \times 10^{4}, 1 \times 10^{2}, 45 \times 10^{6}, 7 \times 10^{6}, 10^{6}$ and $2 \times 10^{6}$ respectively in River Nile water are more or less the same of those found by Haroon et al. (2020) in the Damitta branch of river Nile.

Results gained by Saber et al. (2015) on the intensities of indigenous microorganisms represented by counts of bacteria, fungi and most probable numbers of Azotobacter sp. in Belbeis agriculture drain and river Nile goes hand in hand with our results. They detected the uppermost intensities of the studied indigenous microorganisms in Belbeis drain in summer, where the lowest ones were found in winter. The total aerobic bacterial intensities in Belbeis agriculture drain ranged between 10x10 $\mathrm{CFU} / \mathrm{ml}$ in February and $45 \times 10^{5} \mathrm{CFU} / \mathrm{ml}$ in June, more or less the intensities found in the current study. Such intensities were higher than those found in river Nile that ranged between $15 \times 10^{2} \mathrm{CFU} / \mathrm{ml}$ in February and 30x $10^{5} \mathrm{CFU} / \mathrm{ml}$ in June). They did not find clear variations in the counts of fungi during summer and winter seasons in Belbeis agriculture drain as they ranged between $4 \times 10^{3} \mathrm{CFU} / \mathrm{ml}$ in February and $39 \times 10^{3} \mathrm{CFU} / \mathrm{ml}$ in June. The matching total fungal counts in river Nile water exhibited the same trends between summer and winter samples but at obvious lowers intensities where fungal counts ranged between $14 \times 10$ $\mathrm{CFU} / \mathrm{ml}$ in February and $15 \times 10^{2} \mathrm{CFU} / \mathrm{ml}$ in June. They found that Belbeis agriculture drain water contained MPN of Azotobacter sp. ranging between $11 \times 10^{4} \mathrm{CFU} / \mathrm{ml}$ in February and $18 \times 10^{5} \mathrm{CFU} / \mathrm{ml}$ in June. The corresponding MPN of Azotobacter sp. in river Nile water ranged between $15 \times 10^{2} \mathrm{CFU} / \mathrm{ml}$ in February and $22 \times 10^{4} \mathrm{CFU} / \mathrm{ml}$ in June. 
Table (1) Indigenous microorganisms in river Nile, El-Rahawy and Belbeis agricultural drains waters

\begin{tabular}{|l|c|c|c|c|c|}
\hline \multirow{2}{*}{$\begin{array}{l}\text { Indigenous } \\
\text { microorganisms }\end{array}$} & River Nile & \multicolumn{2}{|c|}{ El-Rahawy Drain } & \multicolumn{2}{|c|}{ Belbeis Drain } \\
\cline { 3 - 6 } & El-hod Site & $\begin{array}{c}\text { El-hadar } \\
\text { Site }\end{array}$ & Bridge Site & $\begin{array}{c}\text { Mosque } \\
\text { Site }\end{array}$ \\
\hline Bacteria & $57 \times 10^{5}$ & $93 \times 10^{6}$ & $18 \times 10^{6}$ & $62 \times 10^{6}$ & $50 \times 10^{6}$ \\
\hline Fungi & $2 \times 10^{4}$ & $1 \times 10^{6}$ & $2 \times 10^{6}$ & $1 \times 10^{6}$ & $2 \times 10^{6}$ \\
\hline Azotobacter sp. & $1 \times 10^{2}$ & $1 \times 10^{3}$ & $1 \times 10^{4}$ & $1 \times 10^{2}$ & $1 \times 10^{4}$ \\
\hline Clostridium sp. & $45 \times 10^{6}$ & $6 \times 10^{6}$ & $7 \times 10^{6}$ & $30 \times 10^{6}$ & $79 \times 10^{7}$ \\
\hline Pseudomonas sp. & $7 \times 10^{6}$ & $27 \times 10^{6}$ & $25 \times 10^{6}$ & $20 \times 10^{6}$ & $6 \times 10^{6}$ \\
\hline PDB & $1 \times 10^{6}$ & $1 \times 10^{6}$ & $25 \times 10^{6}$ & $1 \times 10^{6}$ & $88 \times 10^{6}$ \\
\hline $\begin{array}{l}\text { Cellulose } \\
\text { decomposers }\end{array}$ & $2 \times 10^{6}$ & $2 \times 10^{6}$ & $2 \times 10^{6}$ & $7 \times 10^{6}$ & $75 \times 10^{6}$ \\
\hline
\end{tabular}

El-Ganzori et $\boldsymbol{a l . , ~ ( 2 0 0 0 )}$ carried out a study during the period between March 1998 to July 1999, to investigate the possibility to reuse drainage water at El-Wasat and ElManaifa in Kafr El Sheikh and found that the bacterial count level for most of the sites complies with quality criteria to irrigate the restricted crops according to WHO guidelines given in $\mathbf{1 9 8 9}$.

Comparing the existence and population intensities of the studied indigenous microorganisms in the water of both Belbeis and El-Rahawi agricultural drains with those existing in river Nile indicated, in general, indicated that all the investigated indigenous microorganisms were detected in both studied agricultural drainage water as well as in river Nile water ecosystems (Stahl and Ramadan, 2009). Such finding points to that the pollutants expected to exist in the investigated drainage water samples did not adversely inhibited the main investigated physiological groups of indigenous microorganisms.

Rifaat (2007) elucidated the bacterial quality of river Nile water and examined the indigenous heterotrophic bacteria and identified them using different keys of identification and Biolog metabolic fingerprint system. He ensured the existence of Alcaligenes, Escherichia, Aeromonas, Pseudomonas, Klebsiella, Enterobacter, Rahnella, Xanthobacter, Strepto-myces, Rhodococcus and Arthrobacter therin. The WQI in both Damietta and Rosetta Branches of river Nile during winter season showed that the water 
enters both branches at a good quality then deteriorate downstream before regaining a medium condition. The low flow during winter, together with the pollutant load discharged in their water might explain these changes. The water quality in agriculture drains everywhere always deteriorates downstream and reached alarming levels in the Nile Delta (Sabae and Rabeh, 2007; Ezzat et al., 2011). Dumont (2009) stated that only five agriculture drains, i.e., El-Rahawy in the south, Sobol, El-Tahrrer, Zawiet El-Bahr and Tala are the main source of pollution in Rosetta Branch.

\section{DISCUSSION}

One of the key components of the water strategy in Egypt nowadays is the reuse of low quality water in farming. Despite irrigation with drainage water acclaimed to accomplish vast paces towards evoking agricultural production, from environmental and health aspects, it broadened the dissemination of pathogens and disfigured the microbial biomass in the ecosystem. In the near future, agricultural drainage water will be an important source of the irrigation in Egypt. The continuous expansion of irrigated fields had resulted in an increasing summer water shortage especially east Delta. It is expected that either general or special reuse of treated drainage water would provide a valuable contribution to water supply over the East Delta.

During the last decades, water quality in river Nile downstream from Aswan to northern coast had dramatically changed and became silt-free, less turbid and with less velocity. In spite of the high dilution factor and the high self-purification capacity of river Nile, the impact of low water discharges on the microbial quality of river Nile water is significant especially during low flow years and for sure affected the water quality in agriculture drains. However, a number of policies had been developed to prevent further drainage water degradation in Egypt and ensure enough water supply and sanitation coverage. Instruments targeting both industrial and agricultural sectors are of strict weight and are intend at providing truthful incentives and disincentives to water users for adopting more environmentally friendly practices (Darwesh et al., 2014).

Li et al. (2005) found that although the soils irrigated with drainage water exhibited higher bacterial community richness and diversity, they showed lower microbial functional diversity. Their result indicates that drainage water irrigated soil organisms are functionally weak even though they remain high taxonomic diversity. One possible explanation for this result is a shift from specialist species (harboring specialized functional genes) to generalist species (harboring functional genes shared by many species). Indeed, an increase in the taxonomic diversity of generalist species will not result in an increase in functional diversity, since most species harbor more or less the same genes while in contrast, an increase in the taxonomic diversity of specialist species will result in an increase in functional diversity, since each species harbors a specific set 
of functional genes (Allison and Martiny, 2008). Yet, the comparatively high diversities of specialist species might more accurately reflect the functional community.

Indigenous microorganisms in a given ecosystem are the principal participants and drivers of biogeochemical cycling of elements and are sensitive indicators of a given ecosystem change (Song et al., 2013). The direct microbiological risks associated with the use of drainage water in agricultural irrigation were mainly the disturbance of the indigenous microbial communities in soil ecosystems (Lopes et al., 2015). Nevertheless, our understanding of these aspects has much room for improving. The use of drainage water in irrigation is crucial for overall water management, although it might alter the soil ecosystem greatly. Giaramida et al. (2013) found that the total microbial metabolic activities and the values of functional diversity indices were significantly decreased under drainage water irrigation. Their results indicated that aquaculture drainage water irrigation had exerted adverse effects on soil microbial functional diversity

Irrigation with drainage water produced shifts in ammonia-oxidizing bacteria population in soil ecosystems compared to soils irrigated with freshwater (Ndour et al., 2008; Hidri et al., 2010).

Since Brzezińska (2001) found that, irrigation with municipal drainage water reduced catalase activity at the high irrigation dose and Kayikcioglu (2012) reported a decrease of the activities of enzymes aryl sulfatase, dehydrogenase, urease, alkaline phosphatase and $\beta$-glucosidase in drainage water irrigated agricultural soils. However, Truu et al. (2009) reported a significant increase of alkaline phosphatase in soils irrigated with secondarytreated municipal drainage water over 2 years and Chen et al. (2008) observed an enhancement of various enzymatic activities in soils irrigated with reclaimed drainage water over 10 years. These differences might mainly come from the compounds of drainage water and their concentration, the duration of irrigation and the properties of the soil irrigated that decided the final effects of drainage water irrigation on soil microbial functional characteristics.

In aquatic systems plant-microbe interaction is common, especially on the rhizoplane zone. Plants secrete several organic exudates containing amino-acids, polysaccharides, lipids, phenolic compounds and nucleic acids in their surroundings for protecting the growing soft tissues, for mineral uptake depending upon the local electrochemical environment and to attract microorganisms forming an association of characteristic features performing specific actions. The nature of these interactions varies from positive to negative, depending upon their relationships.

Indigenous microbial populations in agriculture drain ecosystems incorporate both microflora and micro-fauna such as bacteria, fungi, algae and helminthes. Yet, some members of the indigenous microorganisms habitually detected in agricultural drainage water 
ecosystems are pathogenic. The most famous bacteria always found in agriculture drains ecosystems are principally Azotobacter sp., Clostridium sp., Pseudomonas sp., Bacillus sp. as well as phosphate dissolving bacteria and cellulose decomposers. Furthermore, micro-algae and fungi also exist in varied intensities in the agricultural drainage water ecosystems. It is quite evident that the indigenous microbial pollution existing in drainage water varies from site to site and some of which might degrade their water quality.

As far as agricultural drainage water ecosystems are heterogeneous, and the exact microbial intensity of an individual organism is not that easy to determine. The most probable number method was used in getting quantitative data on the intensities of indigenous microorganisms in drainage water as it is a well-known frequently used method up till now. The major weakness of MPN methods is the need for large numbers of replicates at the appropriate dilution to narrow the confidence intervals. MPN does not rely on quantitative assessment of individual cells; instead, it relies on specific qualitative attributes of the microorganism being counted. It estimates microbial population sizes in a liquid substrate, it is tedious, and takes 24 to 48 hours. Williams and Busta (1999) stated that MPN technique is a method for estimating the number of bacteria in varied ecosystems. In such technique, replicate portions of the original sample are cultured to determine the presence or absence of microorganisms in each portion. The replicate portions might be obtained from a serial dilution series. After subdividing the sample, each portion is incubated in a specific media that selects for the growth of certain organisms or groups of organisms. At the end of an appropriate incubation period, each portion is checked for the presence or absence of growth. A calculation is made, or a table is consulted to determine the MPN of target organisms present in the original sample.

An MPN index number represents the MPN of certain physiological group of microorganisms upon the statistical probability of the coincidence of microorganisms in each sample replicate. A 95\% confidence interval represents a range of actual counts in a sample, whereby there is a $95 \%$ probability that any sample containing a number of microorganisms within that range would yield the same result by MPN techniques. The sensitivity of the MPN technique is dependent upon the total volume of sample tested in the smaller portions. The maximum counting range of the MPN technique is dependent upon two variables, the smallest volume of sample tested in the subdivisions and the number of portions of the smallest volume tested. In general, the smaller the volume of the replicates, and the more replicates of each volume you test, the greater the maximum counting range of the test. Chandrapati and Williams (2014) stated that MPN methodology is based on the assumptions that the microorganisms in the sample are evenly distributed as single entities in the sample and that the growth (media and incubation) conditions will allow for the recovery of even a single viable organism. Jha (2016) stated that MPN technique estimates the population density of viable 
microorganisms in a test sample. Inglis and Goettel (2012) mentioned that the MPN method was developed for the enumeration of bacteria in water and had been adapted for use with filamentous fungi.

In conclusion: Indigenous microorganisms usually denote specific mixed cultures of known, beneficial microorganisms that improve soil health, enhance crop production and create a more sustainable agriculture and environment. Srivastava et al. (2017) mentioned that apart from the mutual benefits, plant-microbe interactions also influence the water quality. The rhizoplane is the most active zone in the soil ecosystem (Davies $\boldsymbol{e t}$ al. 2006 and Münch et al. 2007) because of the presence of various microbial communities. Aquatic ecosystems provide plenty of opportunities to the plants and microorganisms to interact just for their survival. In general, plant-microbe interaction relies upon mutual benefits, whereas plants provide oxygen and organic carbon to the microorganisms in return microorganisms provide minerals and metabolites required by plants for their growth.

Despite being in the decade of biological trustworthiness, several constraints are still surrounding sustainable reuse of drainage water as far as the microbial merit is vital for water reuse to survive. Reuse practices routines should be developed within the frame of the recent achievements in environmental biotechnology that are increasingly acknowledged as a potential solution to abundant problems overlaying present situation (Saber, 2001). Sustainable management of low quality water in farming would never be achieved as far as agricultural practices continue to overstress the level of biological and/or chemical contaminants that jeopardizes both flourishing farming and sustainability and necessitates setting new farming systems devoted to following environmental and sustainable approaches.

\section{ACKNOWLEDGMENT}

Thanks go to late Prof. Dr. Essam Hoballah at the National Research Center (Egypt) for his appreciated efforts in the current work.

FUNDING SOURCES: The research paper was funded by STIFA (Science, Technology and Innovation Fund Authority) through the project number 41523 contracted with the National Research Center 2019 and extended till present.

\section{REFERENCES}

Allison, S. and Martiny, J. (2008). Resistance, resilience, and redundancy in microbial communities. PNAS 105:11512-11519.

APHA (2005) Standard Methods for the Examination of Water and Wastewater. $21^{\text {st }}$ Edition, American Public Health Association/American Water Works Association/Water Environment Federation, Washington DC. 
Brzezińska, M.; Stępniewska, Z. and Stępniewski, W. (2001). Dehydrogenase and catalase activity of soil irrigated with municipal drainage water. Pol. J. Environ. Stud. 10: 307-311.

Cai, M.; Yao, J.; Yang, H.; Wang, R. and Masakorala, K. (2013). Aerobic biodegradation process of petroleum and pathway of main compounds in water flooding well of Dagang oil field. Bioresour Technol 144:100-106

Chandrapati, S. and Williams, M. (2014). Total viable counts, most probable number (mpn). Encyclopedia of food microbiology (second edition).

Chen, W.; Wu, L.; Frankenberger, W. T. and Chang, A. (2008). Soil enzyme activities of long-term reclaimed drainage water-irrigated soils. J. Environ. Qual. 37: S-36-S-42

Darwesh, O.; Moawad, H.; Abd El-Rahim, W.; Barakat O. and Sedik, M. (2014). Bioremediation of textile reactive blue (RB) Azo Dye Residues in wastewater using experimental prototype bioreactor. Research Journal of Pharmaceutical, Biological and Chemical Sciences, 5(4): 1203-1219.

Davies, L.; Pedro, I.; Novais, J. and Martins-Dias, S. (2006). Aerobic degradation of acid orange 7 in a vertical flow constructed wetlands. Water Res 40(10): 2055-2063

Dumont, H. Ed (2009). The Nile, Monographiae Biologicae. Origin, Environments, Limnology and Human Use. Ghent University, Department of Biology, Ghent, Belgium.

El-Ganzori, A.; Abdel Gawad, A.; El-Sayed, A. and Hashim. A. (2000). Assessment of the drainage water reuse in the irrigation improvement areas, Kafr El-Sheikh Governorate of Egypt. Cairo Univ., Egypt: 333-344.

Ezzat, S.; Mahdy, H.; Abo-State, M.; Abd El-Shakour, E. and El-Bahnasawy, M. (2012). Water quality assessment of river Nile at Rosetta branch: Impact of drains discharge. Middle-East J. Scient. Res., 12: 413-423.

Giaramida, L.; Manage, P.; Edwards, C.; Singh, B. and Lawton, L. (2013). Bacterial communities' response to microcystins exposure and nutrient availability linking degradation capacity to community structure. Int Biodeterior Biodegrad 84:111-117

Haroon, A.; Tahoun, U.; Sabae, S. and Hamza, W. (2020). Biological Characterization of Water in Damietta Branch of the Nile River, Egypt. SSN 1028-8880 DOI: 10.3923/pjbs.2020.861.882

Hidri, Y et al. (2010). Soil DNA evidence for altered microbial diversity after long-term application of municipal drainage water. Agron. Sustain. Dev. 30: 423-431.

Inglis, G. and Goettel, M. (2012). Most probable number, Laboratory techniques used for entomopathogenic fungi. Manual of Techniques in Invertebrate Pathology (Second Edition).

Jha, S. (2016). The Most Probable Number. Rapid Detection of Food Adulterants and Contaminants. Methods in Microbiology. 
Kayikcioglu, H. (2012). Short-termeffects of irrigation with treated domestic drainage water on microbiological activity of a Vertic xerofluvent soil under Mediterranean conditions. J. Environ. Manag. 102: 108-114.

Li, H.; Zhang, Y.; Zhang, C. and Chen, G. (2005). Effect of petroleum-containing drainage water irrigation on bacterial diversities and enzymatic activities in a paddy soil irrigation area. J. Environ. Qual. 34: 1073-1080.

Lopes, A. et al. (2015). Irrigation with treated drainage water: potential impacts on microbial function and diversity in agricultural soils In Drainage water reuse and current challenges 105-128.

Mañas, P.; Castro, E. and de las Heras, J. (2009). Irrigation with treated drainage water: effects on soil, lettuce (Lactuca sativa) crop and dynamics of microorganisms. J. Environ. Sci. Heal. A44: 1261-1273.

Merck Microbiology Manual (2010) $12^{\text {th }}$ Edition Merck KGaA 64271 Darmstatd, Germany

Münch, C.; Neu, T.; Kuschk, P. and Röske, I. (2007). The root surface as the definitive detail for microbial transformation processes in constructed wetlands-a biofilm characteristic. Water Sci Technol 56(3): 271-276

Ndour, N. et al. (2008). Impact of irrigation water quality in soil nitrifying and total bacterial communities. Biol. Fert. Soils 44: 797-803.

Phung, M.; Castle, J. and Rodgers, J. (2011). Application of water quality guidelines and water quantity calculations to decisions for beneficial use of treated water. Appied Water Science 1: 85-10.

Rifaat, H. (2007). Bacterial Quality of River Nile Water at Cairo Region in Egypt. Suoseura - Finnish Peat land Society ISSN 0039-5471 Helsinki 2007 Suo 59 (1-2): $1-8$

Sabae, S. and Rabeh, S. (2007). Evaluation of the microbial quality of the River Nile waters at Damietta Branch, Egypt. Egyptian Journal of Aquatic Research 33: 301311.

Saber, M. (2001). Clean biotechnology for sustainable farming. Eng. Life Sci. 1(6): 217223.

Saber, M.; Abu-Sedera, S.; Matter, I. and Zaghloul, A. (2015). Seasonal variations in the microbial and pathogenic biomass in low quality water collected from two Egyptian agricultural drains. Research Journal of Pharmaceutical, Biological and Chemical Sciences, 6(4): 1700-1708.

Sadi, T.; Jeffey, L.; Rahim, N.; Rashdi, A.; Nejis, N. and Hassan, R. (2006). Bio prospecting and management of microorganisms. National conference on agro biodiversity conservation and sustainable utilization, pp 129-130

Samie, A.; Obi, L.; Igumbor, O. and Momba, B. (2009). Focus on 14 sewage treatment plants in the Mpumalanga province, South Africa in order to gauge the efficiency of drainage water treatment. Afr. J. Biotechnol. 8: 3276-3285. 
Song, C. et al. (2013). Advances of soil microbiology in the last decade in China. Advances in Earth Science 28: 1087-1105.

Srivastava, J.; Chandra, H. and Kalra, S. et al. (2017). Plant-microbe interaction in aquatic system and their role in the management of water quality: a review. Appl Water Sci 7: 1079-109.

Stahl, R. and Ramadan, M. (2009). Bahr El-Baqar Drain System/ Egypt Environmental Studies on Water Quality Part I: Bilbeis Drain/ Bahr El-Baqar Drain. Forschungszentrum Karlsruhe in der Helmholtz-Gemeinschaft Wissenschaftliche Berichte FZKA 7505 Pimpl Institut für Technische Chemie

Toze, S. (2006). Reuse of effluent water-benefits and risks. Agr. Water Manage. 80: 140159.

Truu, M.; Juhanson, J. and Truu, J. (2009). Microbial biomass activity and community composition in constructed wetlands. Sci Total Environ 407: 3958-3971

Umi KMS, S. (2006). Utilization of microorganisms for sustainable agriculture in Malaysia: current status. Bio prospecting and management of microorganisms. National Conference on Agro biodiversity conservation and sustainable utilization, pp 27-29

Vessey, J. (2003). Plant growth promoting rhizobacteria as biofertilizers. Plant Soil, 255: $571-586$

Williams, M. and Busta, F. (1999). Total viable counts, most probable number (mpn). Encyclopedia of food microbiology. 